Lebedev, S.V. (2021). The aristocracy of the Grand Duchy of Lithuania - Sarmatism, pollination and "remembering" about its origin. Rethinking of history: conflict of facts and hypotheses. Collection of Scientific Articles. European Scientific e-Journal, 7 (13), 7-28. Hlučín: “Anisiia Tomanek" OSVČ.

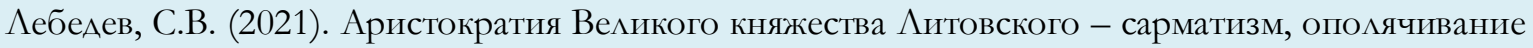
и «вспоминание» о своем происхожАении. Retbinking of history: conflict of facts and hypotheses. Collection of Scientific Articles. European Scientific e-Journal, 7 (13), 7-28. Hlučín: “Anisiia Tomanek" OSVČ.

DOI: $10.47451 /$ his2021-09-004

EOI: 10.11244/his2021-09-004

The paper is published in Crossref, Internet Archive, Google Scholar, Academic Resource Index ResearchBib, JGate, ISI, CiteFactor, ICI, eLibrary databases.

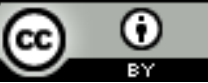

Sergey V. Lebedev

Full Professor, Doctor of Philosophical Sciences

Head of the Department of Philosophy

High School of Folk Arts (Academy)

St Petersburg, Russia

E-mail: servicleb@list.ru

ORCID: 0000-0002-7994-2660

\title{
The aristocracy of the Grand Duchy of Lithuania - Sarmatism, pollination and "remembering" about its origin
}

\section{Abstract:}

The history of the development of the ruling elite invariably arouses interest not only among professional historians, but also among those who are commonly called "ordinary people". Of course, in every country and in every historical epoch, the ruling elite has its own characteristics. The feudal elite of the Grand Duchy of Lithuania has passed a special path stretching for six centuries, repeatedly changing nationality and religion, but at the same time preserving its main features and mentality. The article is devoted to the processes of formation and development of the aristocracy of the Grand Duchy of Lithuania in the period from the 14th to the 20th centuries. The domination of a very numerous and ambitious estate created a unique sociopolitical system of the Grand Duchy of Lithuania, largely inherited by the Polish-Lithuanian Commonwealth after the merger of Lithuania and Poland into one state. After the disappearance of the Polish-Lithuanian Commonwealth from the political map of the world, the aristocracy experienced significant social changes that caused changes in the ethnic identity of the former aristocracy.

\section{Keywords:}

Grand Duchy of Lithuania, Polish-Lithuanian Commonwealth, boyars, Szlachta, magnates, Sarmatism.

Сергей Викторович Иебедев

профессор Аоктор философских наук

зав. кафедрой философии

Высшая школа народных искусств (Академия) 


\section{Аристократия Великого княжества Аитовского - сарматизм, опоцячивание и «вспоминание» о своем происхожАении}

\section{Aннотачия:}

История развития властвующей элиты неизменно вызывает интерес не только у профессиональных историков, но и у тех, кого принято называть «простыми Аюдьми». Разумеется, в каждой стране и в каждую историческую эпоху правящая элита имеет свои особенности. Феодальная элита Великого княжества Аитовского прошла особый путь протяженностью в шесть веков, неоднократно меняя национальность и религию, но при этом сохраняя вои основные черты и ментальность. Статья посвящена процессам формирования и развития аристократии Великого княжества Аитовского в XIV-XX вв. Господства весьма многочисленного и амбициозного сословия созАало уникальную социально-политическую систему Великого княжества Аитовского, в значительной степени унаследованной Речью Посполитой после слияния Аитвы и Польши в одно государство. После исчезновения Речи Посполитой с политической карты мира аристократия пережила значительные социальные изменения, вызвавшие изменения в этнической самоидентификации прежней аристократии.

Ключевъге слова:

Великое княжество Аитовское, Речь Посполитая, бояре, шляхта, магнаты, сарматимизм.

\section{Introduction}

The history of the development of the ruling elite invariably arouses interest not only among professional historians but also among those who are commonly called "ordinary people". Of course, in every country and historical epoch, the ruling elite has its characteristics. The national identity of any country is always based on the history of its ancestors, exploits and achievements. In this sense, the national elites' history will always be relevant and not lose its significance for the historical memory of the nation.

The history of the feudal elites of these states is especially relevant and topical for the peoples of the former Grand Duchy of Lithuania and the Polish-Lithuanian Commonwealth. The legacy of the Grand Duchy of Lithuania is the foundation of the identity of modern Lithuania. The preamble of the Constitution of Lithuania declares with all directness: "The Lithuanian people, who created the Lithuanian State many centuries ago, basing its legal foundation on the Lithuanian Statutes and Constitutions of the Republic of Lithuania, for centuries resolutely defended their 
freedom and independence, preserved their spirit, native language, writing and customs, embodying the natural right of man and People to live and create freely on the land of their fathers and ancestors in an independent Lithuanian state ..." (Constitution of the Republic of Lithuania, 2007). But for its part, Belarus also considers itself (for many reasons) to be the heir of the Grand Duchy of Lithuania. However, Poland especially fiercely claims the legacy of the Grand Duchy of Lithuania, recalling that the Polish-Lithuanian Commonwealth as a state appeared after the unification of the Polish Kingdom and the Grand Duchy of Lithuania. At the same time, a significant part of the Polish aristocracy, which retained its cultural and partly political influence even after the partitions of the Polish-Lithuanian Commonwealth, came from among the "Litvins" (descendants of the aristocracy of the former Grand Duchy of Lithuania). As it can be seen, the disputes on the topic of "whose" state were the Grand Duchy of Lithuania and Polish-Lithuanian Commonwealth, and to which ethnic group and religion to attribute the aristocracy of these states, have not become "history". These problems continue to be "politics", and the current policy, and it makes this topic more than relevant.

The feudal elite of the Grand Duchy of Lithuania has passed a specific path stretching for six centuries, repeatedly changing nationality and religion, but at the same time preserving its basic features and mentality. The most striking thing is that the elite of the former Grand Duchy of Lithuania played a huge political, economic and cultural role both in the Polish-Lithuanian Commonwealth and the Russian Empire. At the same time, the 19th century led to such paradoxical phenomena as the "recollection" of the former Russian origin by a part of the aristocracy, the final pollination of another part, as like the transformation of some representatives of the former Szlachta to an active role in the creation of Lithuanian, Belarusian and Lithuanian national movements. The reason for all these paradoxes lies in the peculiarities of the emergence and development of the Grand Duchy aristocracy.

The project purpose was to study the phenomenon of mass "oblivion" and then "remembering" its former ethnic origin by the peoples who now inhabit the territories of the former Grand Duchy of Lithuania and the Polish-Lithuanian Commonwealth.

Based on the purpose of the study, the author solved the following tasks:

- analyze the transformation of the Boyar class into a family;

- analyze the transition of the clans of Lithuanian origin in the aristocracy of the Grand Duchy of Lithuania to Catholicism; 
- investigate the reasons for the self-destruction of the Grand Duchy of Lithuania and the creation of the Polish-Lithuanian Commonwealth;

- characterize the phenomenon of Sarmatism and its influence on the formation of the phenomenon of mass "oblivion", and then "remembering" their former ethnic origin by the peoples who now inhabit the territories of the Grand Duchy of Lithuania and Polish-Lithuanian Commonwealth.

To achieve the study purpose, the author applied historical, geographical, logical and comparative research methods.

In the study course, the author used the works of well-known experts in the field of the history of Poland and Lithuania, e.g., I.P. Borichevsky, R.A. Kudryavtseva, A.Y. Dvornichenko, M.V. Leskinen, A. Lieven, A.E. Presnyakov, A.V. Tyurin, and A. Vujchik.

\section{Boyars become pans}

In the 14th century, the name "Lithuania" became known throughout Europe due to the emergence of one of the great powers of the Middle Ages - the Grand Duchy of Lithuania. This state, which appeared as if out of nowhere, and then selfdestructed, played such an outstanding role in history that many states claim the legacy of the Grand Duchy of Lithuania today.

Russian culture and the Western version of the Russian language, which was the language of official clerical work and became the basis of the modern Belarusian language, dominated the Grand Duchy. It is significant that the oldest text of the Grand Duchy of Lithuania, the original treaty of the Princes of Lithuania under Prince Algirdas with the King of Poland and the Princes of Mazovia, dated 1350, is written in Russian. The actual creator of the state, Prince Gedimin, chose the doctrine of preserving the cultural and ethnic identity of the local population as the fundamental basis for the legitimacy of his rule, guaranteed "not to destroy the antiquities". The ruler preserved local laws, the rights of feudal lords, the village population and the clergy, the jurisdiction of their local courts, independence in concluding trade agreements. Each Lithuanian prince, receiving a certain city with an adjacent territory as an inheritance, accepted Orthodoxy upon assuming the throne. Prince Skirgailo, who "forgot" about this and remained a pagan when trying to enter the reign in Polotsk, was put by the townspeople on a bald mare and kicked out of the city. As the Polish chronicler, Stryjkowski acknowledged, already in 1332, all the Lithuanian princes, except Keistut, adopted Orthodoxy (Borichevsky, 1851). Orthodox churches stood in all more or less 
significant cities of the Grand Duchy of Lithuania. The Orthodox clergy from the possessions of the Lithuanian princes enjoyed respect and authority throughout Russia. At the end of the 13th century, the theologians Andrei and Simeon, who became bishops of the Tver Principality, arrived in Tver from Lithuania.

The state power in the Grand Duchy after Gediminas death was similar to the ancient Russian appanage system. Each of the descendants of Gediminas embodied the grand-ducal rule. In the second half of the 14th century, the Russian lands' liberation went by Lithuanian princes rapidly. Prince Olgerd Gedeminovich defeated the Tatars at Blue Waters in 1363 (17 years before the Battle of Kulikovo) and occupied Kyiv. Algirdas freed almost all of Little Russia from the Tatars power (except for the Galician Principality captured by the Poles). Also under the rule of Lithuania were Smolensk, Bryansk, and six small principalities of the upper Oka. The border of the Grand Duchy of Lithuania passed less than $150 \mathrm{~km}$ from Moscow. Lithuania strongly influenced Veliky Novgorod (Great Novgorod). Most of the Russian lands were united by Lithuania. The principality's heart was White Russia. The official title of Algirdas sounded like this: "Grand Duke of Lithuania, Russian, Dedich Krevsky, Vitebsk, Polotsk and others." (Presnyakov, 1939) In correspondence with Western European diplomats, Algirdas referred to himself by the title "Rex Lethonye" (King of Lithuania), in correspondence with the Byzantines - vasilea Letvon (king of Lithuania). It seemed that a little more and the whole of Russia would unite under the sceptre of the Gedeminovichi, and Vilna would become its centre.

In 1385, Prince Jagiello concluded the so-called Krevo Union with Poland in the town of Krevo, according to which Jagiello received the hand of the Polish queen Jadwiga and the Polish crown in addition. However, he had to be baptized according to the Catholic rite and baptize the whole country for this at the same time. Lithuanian princes often made predatory raids on Poland. So, from 1246 to 1338, more than 18 Lithuanian campaigns were organized on Polish territories. Now, after the Union of Kreva, the situation has changed.

There was a dynastic and religious union. In the end, this step proved fatal for the Lithuanian Principality.

Since the Grand Duke and all privileged segments of the population became Catholic gentiles, "Latin", the Lithuanian Principality has ceased to be "its" state for the Orthodox Russian population of the Grand Duchy of Lithuania. However, Moscow, the Third Rome, which has never changed Orthodoxy, began to take on the role of a spiritual centre and a place of spiritual aspirations of the Russian population of modern Belarus and Ukraine. Of course, Catholics initially were in 
such a minority that the princes had to reckon with the feelings of the majority of their subjects. Significantly, in the act of the Kreva Union of 1385, Prince Jagiello called himself this way: "We, Jagiello, by the grace of God, the Grand Duke of Lithuania, the Lord of Russia and the heir born" (Act of the Union of Kreva). In this title, Yagailo emphasized the independence of the Rus government, since the concept of "lord" meant at that time a completely independent ruler or an independent state. (Recall that Veliky Novgorod called itself a Master, emphasizing its complete independence). In addition, Yagailo emphasized claims to the whole of Russia and not just the possessions of the Grand Duchy of Lithuania. Finally, being the son of Algirdas from the Russian Princess Ulyana of Tver, Yagailo emphasized belonging to the legitimate ruling dynasty in Russia in his title.

After the last outstanding Prince Vytautas, who showed amazing tolerance for the Middle Ages, who died in 1430, the history of the Grand Duchy of Lithuania is the history of its collapse. The Catholic feudal elite, who felt arrogance and fear of the mass of the Russian population, increasingly gravitated towards Poland, whose king was the Grand Duke, who adopted the Polish language and customs. The ruling elite has renounced the faith of their ancestors, language, and even a sense of loyalty to the state. The Russian Catholic elite robbed their fellow tribesmen, who stubbornly preserved the Orthodox faith and Russian identity, in a way that foreign invaders would not have done.

The starting conditions of the Grand Duchy of Lithuania were incomparably better than those of Moscow. But in the historical dispute, it was Moscow that turned out to be the winner. And the reasons were the peculiarities of the political, social and cultural development of the Grand Duchy of Lithuania.

The Grand Duke of Lithuania, although he had the title "lord" among the epithets, was not an autocrat. Even with such strong personalities as Gedemin, Algirdas, Vytautas, the grand dukes had to rule together with the closest nobles. The Grand Duke exercised his power through loyal courtiers and servants, whom he rewarded with lands in every significant region of the country. Already Yagailo, introducing Catholicism in the principality to attract at least some of the Orthodox feudal lords to his side, granted them considerable benefits.

The Gorodel Union of 1413 was of great importance for the gradual establishment of the system of the magnate oligarchy. One of the conditions of the union was the equating of the boyars of the Grand Duchy of Lithuania to the Polish Szlachta. From that moment, any Lithuanian nobleman, if he converted to Catholicism, became a Polish nobleman. His family was attributed to one of the Polish coats of arms, which united several noble surnames. 47 boyar families of the 
Grand Duchy of Lithuania, who converted to Catholicism, received the right to use Polish coats of arms. In the Grand Duchy of Lithuania, the same administrativeterritorial division was introduced with Poland into voivodeships, provinces and old towns. The Gorodel Union became a symbolic basis for the polonization (pollination) of the nobility of the Grand Duchy of Lithuania.

And while the grand dukes, who lived in remote areas of the country, and then mostly in Poland, interfered less and less in domestic politics, some powerful magnate families took powerful roots in the fief lands inherited them. Some of them ended up among the largest landowners in Europe. Over time, as the grand dukes, who became part-time Polish kings, lived outside the Grand Duchy of Lithuania, a significant part of the state's lands were privatized by several dozen noble families. Representatives of the noblest feudal families in the Polish manner began to call themselves pans. The most powerful of the lords were called magnates (from the Latin "magnatus", i.e., great, outstanding). The magnates had their armies of their serving men. The wealth of the magnates is evidenced by the fact that in the 16th century, 14 magnates exhibited 3,892 mounted warriors in the grand-ducal squad, approximately 278 from each. Among the magnates, the Radziwills family stood out, who, according to the official version, descended from the ancient Lithuanian pagan priest Lizdeika. The Radziwills with their power, relying on their huge landholdings, which had over 28 thousand "dyms", i.e., the families of their serfs leading the economy, could well be equal to the grand dukes. No less powerful magnates were the Sapieha, a family of Russian origin from Smolensk.

At the beginning of the 16th century, the Orthodox boyars of the Grand Duchy of Lithuania, mainly consisting of descendants of Russian appanage princes and their serving boyars, formed into a clear class group. The Orthodox nobility of the Grand Duchy of Lithuania consisted of 23 princely and 42 boyar families. For the most part, these boyars had surnames (formed on behalf of an ancestor or ancestral possession) ending in ...ich. These were Andrievichi, Baltromeevichi, Bartoshevichi, Bogdanovichi, Bortkevichi, Vitkevichi, Volovichi, Volodkovichi, Grigorovich, Dovyatovich, Ivashkevich, Lavrinovich, Lukashevich, Martynovich, Mateevichi (Macievichi), Mickevichi, Nemirovichi, Pavlovichi, Petrovichi, Sakovichi, Stankevichi, Tomashevich, Khodkevichi, Khreptovichi, Shimkevichi, Yurevichi, Yanovichi, etc. Boyars from the lands of present-day southern Lithuania and the northwest of modern Belarus (Black Russia), where Catholicism was already widespread, often had double surnames (one for Latin spelling, the other 
for Russian), such as Bonch-Bruevich, Dolivo-Dobrovolsky, Lozino-Lozinsky, May-Mayevsky, Tur-Tubelsky.

The descendants of very ancient nobility, who build their genealogy in the times of Kievan Rus, usually had generic surnames ending in “...skiy", after the name of the ancestral possessions. These were: Drutsky (from the sovereign princes of Drutsk), from which various lines were later distinguished - DrutskySokolinsky, Drutsky-Lyubetsky, etc., Zaslavsky (from Zaslavl in modern Belarus), Nesvitsky, Oginsky (from the nickname Fire of Prince Kozelsk Grigory Titovich), Ostrog, Svyatopolk-Mirsky (owners of the city of Mir), Chartorysky (from the city of Chertoriy) in Volhynia, etc.

\section{Conversion to Catholicism}

Initially, all of the above aristocratic families belonged to the Orthodox faith. However, soon, the spread of Catholicism among the boyars accelerated, and they joined the magnates of the Grand Duchy of Lithuania. There were quite a few families of Lithuanian origin in the aristocracy of the Grand Duchy of Lithuania. In addition to the Radziwills, there is no doubt that the Songailo, Montvids, Dovgirds had Lithuanian origin. However, they did not have large possessions and did not belong to the top of the aristocracy.

Strictly speaking, the richest magnates with princely titles of Gedemin or Rurik blood were only part of the Szlachta - numerous privileged, originally serving class. The origin of the word "Szlachta" is very uncertain. It comes either from the Upper German "slahta”, i.e., genus, or the German word "schlacht", i.e., battle. There is also a version that the Szlachta was warriors who accompanied their prince on the way along the shlyakh, i.e., steppe road. At the same time, gradually the old concept of "boyars" almost disappeared, now denoting only the lowest part of the personally free rural population. The so-called "armoured boyars" existed in the form of an intermediate group between the Szlachta and peasants until the 18th century. The Szlachta concept came from Poland, where the nobility was mentioned as a knightly estate since the 11th century. The Szlachta, originally formed as a grand-ducal squad, then turned into a military service class. Gradually, by the 16th century, due to the increase in its political powers, the Szlachta lost its full military function. It transformed into a powerful political institution that dealt with other issues, issues of power. The Szlachta solved the problems of strengthening their influence on the Grand Duke, governing the country, rather than issues of defence and strengthening military power, the number of victories of Lithuanian weapons decreased, and, so, mercenaries appeared in the Lithuanian 
army (Kudryavtseva \& Dvornichenko, 2014). Unlike autocratic Moscow, in which all estates had to serve the state, in Lithuania, Szlachta had only privileges, but they were not supposed to serve anyone. It is in the gradual Szlachta transformation into a parasitic social group that lies the reason for the decline of the Grand Duchy of Lithuania and the reason for its unification with Poland in which, however, there was also the omnipotence of the Szlachta, and which later also ceased to exist as a state. At the same time, the Szlachta was numerous - at the beginning of the 16th century, there were about 20 thousand Szlachta families. For the most part, the Szlachta was poor and served magnates, legally the same as them, the Szlachta, but richer and more powerful.

The formation of the Szlachta as the ruling class mainly falls on the 15th century. Legislative acts of the 1430s-40s of Svidrigailo, Sigismund and Casimir formalized the special status of the nobility of the Grand Duchy of Lithuania. Over several decades, she gained many rights and privileges that Western European and Polish knighthood achieved earlier, but it took much longer and more complex to achieve. After that, the process of forming the noble estate went rapidly. The second half of the 15th century was the time of the formation of a new feudal magnate elite, which significantly pushed the ancestral (princely) aristocracy. The privilege (legislative act) of Casimir IV finally established the magnate oligarchy in the Grand Duchy of Lithuania in 1447. It confirmed the right of magnates to elect a new monarch after the death of the previous one. By the 16th century, magnates controlled a third of the lands of the Grand Duchy. The privileges of 1507, 1511, and other years established the personal inviolability of the Szlachta, the inadmissibility of confiscation of the Szlachta property and its punishment without trial. The Szlachta received the right of trial for many categories of persons living in their possessions. Tax immunity has become widespread. The nobleman's estate could pass to the Grand Duke only in the event of his death and in the absence of his heirs.

Gradually, the monarchy began to become elective. Initially, however, the princes were chosen from the house of Gedemin. The prince was elected by the lords from the representatives of the princely dynasty. The Grand Duke commanded the armed forces, legislative acts were issued on his behalf and a court was held. He was in charge of diplomatic relations with other countries, the declaration of war and peace. He was appointed to public positions and disposed of state property.

Under the Grand Duke, since 1401, the Sejm (according to the texts of the chronicles, the Pan-Rada) acted as an advisory body. General Sejm was called valny. 
The Sejm consisted of persons who held the highest state posts, members of the Grand-ducal family and representatives of the wealthiest influential families. Initially, the Sejm was an advisory body, but, as the economic and political role of the feudal nobility grew, the Sejm and the prince (and often instead of him) exercised legislative, executive and judicial power. The privilege of Casimir IV in 1447, which confirmed the right of princes (magnates) and lords (high boyars) to elect a new monarch after the death of the previous one, became the assertion of oligarchic power. Since the middle of the 16th century, the Valny Sejm consisted of the State Council, which became known as the Senate, and of the deputy ambassadors, who made up the Embassy Hut.

The Sejm gradually became the most important authority. The Sejm collected extraordinary taxes named "serebrscbina", determined the conduct of war and peace. In 1566, the Sejm decided that no new laws could be passed at all without its participation. As it can be seen, the monarchy in the Grand Duchy of Lithuania was sharply limited, but it was not democracy, but the rule of a narrow oligarchic group of magnates.

After 1385, Catholicism continued to spread not only among pagans but attempts were made to catholicize the Orthodox ethnic majority. Vytautas (Witold) built more than 30 Catholic churches. Most of them received ethnic Lithuanian lands. A church of St Anna was erected in the castle of Vilna, and a large Franciscan church was built in the city itself. However, already under Vytautas (Witold), Catholic churches began to be built on Russian lands (in Vitebsk, Pinsk, Volkovysk, Brest, Grodno, Lutsk). Monks of various Catholic orders also began their activities there.

The Orthodox majority began to be discriminated against. In 1499, in the materials of the next Polish-Lithuanian union, the Orthodox population rights were no longer mentioned. Significantly, the Catholic Church refused to recognize Russians as Christians in general. In official documents, the term "Christian" meant only a Catholic. The Orthodox were called "schismatics", i.e., "dissident" (although, strictly speaking, it was the Roman Church that split Christianity). The Orthodox, who wanted to convert to Catholicism, had to be baptized a second time. Orthodox baptism was not recognized. Therefore, the documents clearly distinguished "baptizatus" and "schismaticus" (baptized and schismatic). Since the Orthodox were exclusively Russian, they often simply wrote: "ruthenus vel cbristianus" (Russian or Christian). Interfaith marriages were not allowed - when married to a Catholic or a Catholic, the spouse was obliged to convert to Catholicism. In fairness, it should note that this law was previously ignored and only after the 
unification of Lithuania and Poland began to be strictly enforced. Many former Orthodox princes who converted to Catholicism staged a wild rite of "crossing" their long-dead ancestors. Coffins with the ashes of their ancestors were dugout. The dead were "baptized" according to the Latin rite.

\section{Self-liquidation of the Grand Duchy of Lithuania and the creation of the Polish-Lithuanian Commonwealth}

The ongoing Muscovite-Lithuanian wars also invariably ended in Moscow's victory. The Livonian War, which began in 1558, put the Grand Duchy of Lithuania on the brink of destruction. Although the Grand Duchy of Lithuania was richer than the Muscovite Kingdom, the magnates and Szlachta did not want to shed their blood even for the sake of their country. The Szlachta aspired to have new privileges and considered itself so free that it did not want to incur any duties. So, in 1567, most of the nobles simply did not show up for the gathering of the Grand-ducal army. The Szlachta did not want to pay money for a mercenary army. The way out was found in the merger with Poland.

As the modern researcher A.V. Tyurin figuratively wrote: "as a sutler follows a soldier, so Poland follows Lithuania, seduces her with the charms of civilization, Polish golden apples: comfortable dwellings, balls and performances, beautifully dressed women. Until recently sitting in a swamp, Lithuania has nothing to oppose Poland, chatting in Latin and reading Plautus with Terentius; Moscow's influence is negligible, somewhere across the sea, Byzantium is bending, robbed and humiliated by the Latins. And the Lithuanian feudal lord changes the animal skin for doublet and trousers with a codpiece and bear dances around the campfire for a krakowiak and a minuet (menuet). Poland could give the Lithuanian elite something more than culture, it gave an ideology of domination disguised as Szlachta liberties. The Lithuanian nobility will now be Polonized, step by step receiving dubious gifts in the form of Szlachta privileges, the Western Russian peasantry will become more enslaved." (Tyurin, 2020)

And in 1569, another union was concluded in the Polish city of Lublin, this time a state one. The Kingdom of Poland and the Grand Duchy of Lithuania united into one state. In historical literature, this state is called by the beautiful name of the Polish-Lithuanian Commonwealth, although, strictly speaking, this is not the state name, the designation of its political structure. Polish-Lithuanian Commonwealth (from Polish "rzecz" - thing and Polish "pospolita" - general) is a literal translation from Latin into Polish of the legal concept Res Publica. Historically, "republic" is translated into Russian as "common cause" or "common thing". 


\section{Sarmatism}

Any social order requires an ideological justification. In Poland and Lithuania, Sarmatism has become such an ideology. Sarmatism (or Sarmatism) was the ideology that prevailed among the nobility of the Polish-Lithuanian Commonwealth from the 16th to 18th centuries. Sarmatism influenced in the past and continues to impact culture, politics, ethical norms, and social relations in Poland and Lithuania now. As a modern researcher notes, "the term 'Sarmatism' is usually understood as a set of features of the Polish Szlachta's worldview, lifestyle, system of views, behavioural stereotypes and the corresponding culture." (Leskinen, 2002)

The fundamental idea underlying Sarmatism is the origin of the Polish Szlachta from the ancient Sarmatians who conquered the Slavs. Thus, according to Sarmatism, the Szlachta ("naród szlacheckel) as the dominant class is more different people than the peasants and burghers of Poland. If the dominant class was foreign in many Slavic lands, originating from real foreign conquerors and their descendants, then in Poland and Lithuania, the ruling Szlachta invented the conquest of their country. Similar phenomena of social racism existed in other Slavic countries, e.g., in Russia, too, the aristocracy invented "Varangian", "German" or "Horde" ancestors. In some Western European countries, the aristocracy also tried deriving its origin from the ancient Goths (as in Spain) or the Germanic Franks (as in France). But nowhere have such theories received such attention and achieved such influence as in Poland.

The reason was that in centralized monarchies, such as in the Russian autocracy, a strong central government could limit the claims of the nobility and provide vertical mobility to all social classes and strata. In Russia, in the sovereign's service, any commoner could, in principle, rise to the very foot of the throne. In Poland, the nobility limited the king power and needed an ideological justification for their domination. Unlike the Russian nobility, the service class served the Tsar and the Fatherland the Szlachta were only a privileged class that had rights but owed nothing to anyone. There were a lot of Szlachta - almost $10 \%$ of the population. It is not surprising that the Szlachta morality was assimilated by the Polish nation. All the noble virtues, including such as a principled unwillingness to work, swagger, arrogance, called honour, rebellion, and at the same time servility to the power of this world, really became the basis of the behaviour of the nobility. However, a country ruled by such a class is not viable. 
Sarmatism turned out to be especially convenient for a part of the Western Russian elite of the Grand Duchy of Lithuania and contributed to its Catholicization and polonization. Many Rurik blood princes and Russian boyars of the lands of Little and White Russia accepted Catholicism, switched to Polish. The idea of Sarmatism calmed their conscience, especially in relation to these renegades to their serfs from among ordinary Russian people, who retained their faith, their language and nationality. It is not surprising that Sarmatism had the greatest influence among the polarized Szlachta and magnates in the Western Russian lands. Magnates and Szlachta who changed their faith, language and culture, in full accordance with the Sarmatian theory, could consider their serfs as "cattle", descendants of the conquered, whom they, true Sarmatians, rule by right of conquerors. And the fact that a significant part of the Polish Szlachta was polarized Russian (and to a small extent, Zhmudin, i.e., Lithuanian proper) princes made them especially malicious Russophobes. In general, for a long time, the aristocracy of the former Grand Duchy of Lithuania remembered its Russian origin. Gente Polonus, Natione Ruthenus - a Pole of the Russian family - such was the selfconsciousness of the noble Szlachta in the 16th and 17th centuries. Sometimes the term "Gente Golonus, Natione Lituanus" (a Pole of Lithuanian descent) was used. However, it did not mean the Lithuanian ethnic origin of the nobleman, but that he or his ancestors came from the lands of the Grand Duchy of Lithuania. However, gradually the idea of their origin from the mythical Sarmatians cut off the memory of their Russian origin of the Szlachta of the Western Russian lands.

Since ancient authors called Sarmatia a vast territory from the Carpathians to the Urals, the theory of Sarmatism also justified Polish claims to the eastern lands, which "rightfully" should belong to the Polish Szlachta. For example, Martin Pashkovsky claimed that Poles are the lands' heirs on the Oka, Volga and Don, and called Russian stepsons of Sarmatians who have no rights to these lands. As always, when a Western (or claiming to be Western) country is trying to conquer someone, then this is all called "liberation". At the beginning of the 17th century, during the period of the Polish invasions of troubled Russia, a certain Pavel Polchovsky called the upcoming territorial acquisitions of Poland an extension of "przestrzeni wolności" ("freedom spaces").

The Sarmatism theory began taking shape from the 15th century, when the Polish Kingdom started rising after the victory at Grunwald in 1410, accompanied at the same time by the strengthening of the power of the magnates and Szlachta, which limited the king power. The beginning of Sarmatism can be considered the patriotic writings of the prominent Polish historian Jan Dlugosz (1415-1490), who 
wrote the History of Poland in 12 volumes, in which, however, he also expounded biblically and world history, starting from Adam. To lengthen Poland's history, Dlugosz began the history of his country with the settlement of the descendants of Japhet in Europe. Dlugosz was the first to identify the ancient Sarmatians with the Poles. However, Dlugosz also considered all Slavic peoples to be Sarmatians. He was a serious scientist making extensive use of ancient chronicles and did not give much scope to the imagination.

The truly Sarmatian theory was created by Matvey Mekhovsky (1457-1523), a major geographer and historian, who published in 1508 a geographical and ethnographic description of the lands east of the Vistula called Tractatus de duabus Sarmatiis ("A Treatise on two Sarmatians"), which became the basis of the theory. Mekhovsky believed that Sarmatia stretches from the Vistula in the west to the Caspian Sea in the east and is divided into European and Asian by the Tanais (Don) River. So, already in the 16th century in Polish culture there was a belief that the lands and peoples east of Warsaw were a kind of "Polish America", and it is inhabited by savages. The sacred duty of a Pole is to develop these lands, as like to baptize the aborigines (Orthodoxy was not considered Christianity). The PolishLithuanian Commonwealth was regarded as an "Outpost of Christianity" (in Latin Antemurale christianitatis, in Polish Przedmurze Chrześcijaństwa), which meant only Catholicism in eastern Europe.

In the 17th century, Sarmatism became the dominant ideology of the Szlachta. Along with the pseudo-historical theory of the conquest of the Slavs by the ancient Sarmatians, militant Catholicism also became the main component of Sarmatism. The belief that the Polish-Lithuanian Commonwealth, thanks to its loyalty to the Catholic faith, has a great future, became the basis of Sarmatism. Interestingly, the Franciscan monk Wojciech Dembolecki, in one of his works entitled "Proof of a Sovereign World State", published in 1633, announced that the Polish-Lithuanian Commonwealth would rule other nations soon because Adam and Eve spoke Polish in paradise (Vujchik, 2020).

Sarmatism in this era also became the basis of the Szlachta mentality. Among the virtues of a true Sarmatian were called chivalry, which includes not only military bravery but also a heightened sense of self-esteem (bonour), ready to rebel against the king himself if he encroaches on his "rights". In battle, the main thing for a nobleman was to demonstrate personal bravery and not at all the success of the entire battle. It is no coincidence that the Polish armed forces won many battles but lost most of the wars. It was believed that a true nobleman should be decorated 
with scars received in battles. If there were none, they went to the barber to make them harmless but visible incisions.

Chivalry also meant a gallant attitude towards women and contempt for hoarding and bourgeois "making money". Entrepreneurship was condemned in the Sarmatian environment because a true Sarmatian should not be greedy for money like Jews. However, the real Szlachta has never been disinterested. On the contrary, the venality and greed of the Szlachta have always existed. Judicial figures were especially famous for corruption in the Polish-Lithuanian Commonwealth, and on the contrary, the few Orthodox in Polish courts were known for their honesty. Catholic preacher Tomasz Mlodzianowski explained this by saying that Gentiles do not take bribes because the devil does not tempt them because they, being heretics, will go to hell anyway. So, the devil directs all efforts to Catholics Janusz Tazbir about the Sarmatians. The black legend of the Polish Szlachta is the work of priests, 2008).

Also, the Sarmatian nobleman was distinguished by a familiar attitude towards other noblemen (familiarity) and complete contempt for any labour activity, except for the service of a warrior and a rural landowner. Idleness was considered almost the duty of a true Sarmatian. Impoverished Szlachta could become highwaymen or even beggars on the porch of the church, but they still considered themselves above all those who do not belong to the Szlachta class and despise those who gave them alms.

Sarmatism has created a certain fashion for a pseudo-oriental costume. Zhupan, kuntush, chamarka, confederate cap eventually turned into elements of the national costume in Poland. It was only in the 18th century that the Szlachta began to wear Western European tailcoats and camisoles. However, during the uprisings of the 19th century, many Polish nationalists, who often did not have a Szlachta origin, began defiantly wearing "Sarmatian" clothes. Hanging long moustaches in Poland are still called Sarmatian.

Sarmatism had a great influence on the Polish art of that time. In particular, poetry flourished (largely in Latin). A special kind of fine art was called the "Sarmatian portrait". In such portraits, according to certain rules, nobles were depicted, always dressed in a kuntush and a zhupan and with a sabre with a special hairstyle.

Considering themselves descendants of mythical conquerors, the Szlachta was most proud of the nobility of their blood. To this end, the Szlachta composed magnificent pedigrees for themselves, certified by all sorts of ancient "letters" with coats of arms, royal signatures and seals. Many Jewish offices "specialized" in the 
manufacture of such genealogies, stamping dozens of noble letters to everyone willing to pay for them. However, many scammers blackmailed such false Szlachta. In particular, the "Book of Boors" (Liber chamorum) by Valerian Nekanda Trepki, written in the first half of the 17th century, was of great importance for the Sarmatians, in which a list of 2,500 plebeians posing as Szlachta was given. It was a banned book, distributed anonymously in handwritten copies because no one dared to print it. It failed even in interwar Poland.

One way to prove their belonging to the Szlachta was the testimony of 12 witnesses. It is not surprising that, according to the memoirs of witnesses of the era, at every tribunal, there were such witnesses who testified even for a bowl of soup.

Finally, Jews, who converted to Catholicism, could receive the nobility dignity based on the law of the Grand Duchy of Lithuania, which was in force until 1764. This practice took on such a scale that sometimes Catholics of a simple rank themselves accepted Judaism and then returned to Catholicism again to receive the coveted nobility dignity.

Sarmatism as an ideology survived the Polish-Lithuanian Commonwealth. Polish authors such as Adam Mickiewicz and Henryk Sienkiewicz (both, by the way, natives of the lands of the Grand Duchy of Lithuania) wrote about the Sarmatian virtues, unwittingly idealizing them. At the same time, the texts of these popular authors are often perceived as historical primary sources (Leskinen, 2002). The partition of Poland did not put an end to Sarmatism, but only changed its form. Many qualities of Sarmatism have entered the mentality of a significant part of the Polish nation. Such features as an extremely exaggerated idea of Poland's role in history, an arrogant racist attitude towards Eastern Slavs, an inferiority complex of a philistine in the nobility, a craving for beautiful words and gestures, which often have no business behind them, the insignificance of the spread of ideas of Slavic unity in Poland, low work ethic, claims to "eastern Kres", the complex of the country before which everyone is to blame - all this is the legacy of Sarmatism.

\section{5. "Sarmatians" remember their roots}

The Polish-Lithuanian Commonwealth was divided into three sets by neighbours in 1772, 1793 and 1795. Although the Polish aristocracy tried to regain the fullness of its former power by supporting Napoleon and raising uprisings, all these attempts led to defeats. After all these uprisings, the traditionally patronizing policy of the Russian Imperial authorities towards the Polish Szlachta (legally 
considered part of the Russian nobility) changed. And now it has become unprofitable to be a "Polish aristocrat".

The fate of a significant part of the local nobility can serve as an indicator of ethnic processes in the lands of the former Grand Duchy of Lithuania. Most of the local Szlachta were of Russian origin and professed Catholicism. But the policy of eliminating the special rights of the Szlachta carried out by the authorities of the Russian Empire, the ruin and declassification of many nobles sometimes led to unexpected variants of the ethnic identity of the former noble Szlachta. Many aristocratic families remembered their Russian origin.

However, the aristocrats of Lithuanian origin are of particular interest. There was such example as the history of the princely family of the Skirmunts (touching, however, on their fate in the 20th century). Skirmunty is a Lithuanian Zhmudinsky (Zhemait) princely family known since the 14th century. The surname "Skirmunt" (Shkirmantas) has several meanings in Lithuanian - to separate, highlight, mark. However, according to the official legend, the dynasty originated from a certain Skirmunt, about whom nothing concrete is known. In 1355, Prince Vasily Skirmunt of Pinsk of the Orthodox faith is mentioned in the chronicles. Almost two hundred years later, in 1551, the Polish Queen Bona granted Bogush Skirmunt a land allotment in the village of Plotnitsa (now Stolinsky district of the Brest region of Belarus), for which he undertook "military zemstvo service". In the 16th century, the Skirmunts, who did not have a princely title, nevertheless became part of the aristocracy of the Polish-Lithuanian Commonwealth. The ancestral possessions of the Skirmunts from that time were located in the southern part of modern Belarus, in Polesie near Pinsk. Of the Lithuanian Skirmunts proper, the last was the bishop of Utyansky (from the city of Utena in modern Lithuania), who died in 1718. After him, nothing is known about the Skirmunts in Lithuania. According to the documents of the Pinsk master in 1777, Adam Skirmunt was the voit (headman) of the city. Near the church of the village of Belt (Stolinsky district), the grave of Alexander Skirmunt (1793-1845), marshal (leader of the nobility) has survived to this day Pinsk County. Alexander (1798-1870), a major entrepreneur, one of the organizers of sugar refining production in Russia, was also engaged in the production of the grapes in Crimea. Elena Skirmunt (1827-1874), who studied painting and sculpture in Vilna, Berlin and Paris, became famous in art, and her daughter Constance (1851-1933) became a famous Polish writer. The son of Alexander Alexandrovich Skirmunt, Roman, became a Belarusian nationalist, a deputy of the First State Duma (from Minsk province), as like figure of the "Belarusian People's Republic". In the autumn of 1939, Roman Alexandrovich 
Skirmunt, along with his sister's husband Boleslav, fell victim to lynching in the autumn of 1939, when local supporters of the Soviet government dealt with figures of the Polish authorities in western Belarus.

Simon (Semyon) is also known Skirmunt (1747-1835). He made a brilliant career, becoming a marshal of the Brest voivodeship and an ambassador (deputy) of the Sejm since the end of the Polish-Lithuanian Commonwealth. The most famous family representative was his son, his cousin Konstantin Genrikhovich (1866-1949), who was a member of the State Council of the Russian Empire before the October Revolution and after the revolution, felt like a Pole and moved to Poland. He was the Polish Ambassador to England and Minister of Foreign Affairs. One of the Skirmunts at the end of the 19th century was a bishop in the Vatican.

In addition to Belarusian Skirmunts, we can also talk about Russian Skirmunts. Among them stands out Sergey Apollonovich (1862-1935) - publisher and bookseller, a friend of Gorky. He lived in Moscow and became famous as one of the organizers and sponsors of the "Society for the Promotion of Public Folk Entertainment" This society included directors K.S. Stanislavsky and V.I. Nemirovich-Danchenko, writers V.A. Gilyarovsky and T.L. Shchepkina-Kupernik, patrons P.M. Tretyakov and S.T. Morozov. Sergey Skirmunt headed the publishing house Trud, which released the album Gallery of Russian Writers with 250 portraits and brief critical and biographical essays, as like translations of works by Western European authors with a pronounced political orientation, the connection with the Social Democrats became closer. During the first Russian Revolution, Sergei Skirmunt began publishing a Cheap Library, which included dozens of pamphlets of political content, including works by K. Marx, F. Engels, and several Western European figures of the socialist trend. In 1905, Skirmunt undertook the publication of the legal Bolshevik newspaper Struggle, in which he invested the general funds. Only 9 issues were released, and three of them - after the arrest of the editor. The last issue came out with an appeal "To all workers, soldiers and toilers?" calling for a general political strike and an armed uprising. In November 1907, Skirmunt was sentenced to 3-year imprisonment in a fortress, but he managed to go abroad. After the amnesty in 1915, he came to Russia for a short time, and finally returned in 1926. In the last years of his life, Sergey Skirmunt worked in the People's Commissariat of Labor, GosTorg, the Association of Scientific and Technical Publishers.

During the First World War, Ivan Skirmunt became famous as a staff captain of the Caucasian Equestrian Mountain Artillery Division, an observer pilot of the 
Black Sea Air Division. On February 24, 1917, during an aerial reconnaissance, he was mortally wounded. "For valiantly performed reconnaissance under heavy enemy fire", he was posthumously awarded the St George Weapon. Probably, Ivan Skirmunt became the last hero of the monarchy.

Bearers of the surname Skirmunt, Skirmuntov, Shkirmuntov, are known in the Soviet era.

The fate of the Gedroyites, descendants of a certain Prince Gedrus, who allegedly lived in the 13th century, is no less indicative. In the era of the PolishLithuanian Commonwealth, the Gedroyites were rich and powerful. In the Russian Empire, the Gedroyites also made successful careers, giving Russia several generals, artists and scientists. So, Vera Giedroyts became one of the first female surgeons in Russia, Raisa Giedroyts, by Kudashev's husband, wrote the famous children's poem $A$ Christmas Tree Was Born in the Forest.

Some Gedroits remained Poles. So, Jerzy Giedroyc, after the Second World War, published the magazine Culture in Paris, coordinating the activities of anticommunist organizations in the West and inside socialist Poland. Usually, the socalled Giedroyc-Meroshevsky Doctrine is associated with the name Jerzy Giedroyc. This foreign policy concept of the Polish emigrant circles has an impact on the modern politics of Poland. The doctrine was an article by the political scientist Juliusz Meroszewski, published in 1974 in the Polish emigrant magazine Culture, edited by Jerzy Giedroyc. The main paradigms of the doctrine were the final rejection of Poland from the eastern lands of the historical Polish-Lithuanian Commonwealth, the collapse of the USSR and the creation of independent Lithuania, Belarus and Ukraine. It was assumed that the countries for which the abbreviation ULB was invented (Ukraine, Lithuania, Belarus) would become satellite states of Poland. As you can see, this is another attempt to realize the dream of Poland from sea to sea. Needless to say, the main drawback of the Doctrine is that Poland is not able to pursue an independent policy at all. However, cleverly using Polish complexes, the West skillfully uses Poland as an instrument of its anti-Russian and anti-Slavic activities.

No less indicative is the fate of the Belozor family, as it was written in the old spelling, Bilozor (sometimes spelt Byalozor), descendants of Montvila, the son of Gedemin. The Byalozor family is unique for its contribution to the history of Christianity, giving the world three bishops: Catholic Bishop Jerzy of Vilna (17th century), Uniate Metropolitan Marcian (17th century), Orthodox Bishop Alexander (1866-1933). 
There are many similar examples. Only the fact of a sharp change of nationalities and religion by representatives of the former elite of the former Grand Duchy of Lithuania is important. At the same time, the traditions, mentality and culture of this aristocracy also influence the modern political, social and cultural processes of Poland, Lithuania, Ukraine and Belarus. Without studying the aristocracy evolution, it is also impossible to consider the prospects for the development of these countries.

\section{Discussion}

When considering this topic, the author suggests continuing the discussion of the following postulates that were put forward in this scientific article:

1. The Grand Duchy of Lithuania was an East Slavic state (Other Russia) created and united by a dynasty of "Lithuanian", i.e., Baltic origin.

2. The development of the Grand Duchy of Lithuania went directly opposite to the Moscow autocracy (instead of rigid centralization with the leading role of the service class, the aristocracy of the principality privatized the state, which ultimately led it to unification with Poland).

3. The Polish-Lithuanian Commonwealth inherited all the vices of the Grand Duchy of Lithuania and, due to the omnipotence of the aristocracy, was divided by its neighbours.

4. The aristocracy of the Grand Duchy of Lithuania, forming a single corporation with a strong corporate spirit, was originally multi-ethnic and, in the first centuries of its existence, even distinguished by multi-confessional. But with the establishment of the dominance of the Catholic religion and cultural and linguistic polonization, which manifested itself in the ideology of Sarmatism, the unification of the estate took place.

5. Despite the polonization, the aristocracy of the former Grand Duchy of Lithuania retained the memory of its ethnic origin, for this reason, as part of the Russian Empire, when the Polish Szlachta ceased to be prestigious, there was a "recollection" of its roots in a part of the aristocracy.

\section{Conclusion}

The history of the ruling class of the Grand Duchy of Lithuania is largely unique in European history. Changes in the ethnic identity of the ruling elite in the Middle Ages, and many ways in Modern Times, are not such a rare phenomenon. One can recall how the chivalry from French Normandy, after the conquest of England in 1066, gradually began to consider themselves true Englishmen while 
maintaining the French language and culture in their midst for several centuries after the conquest. In the Kingdom of Hungary, a huge role was played by completely magyarized clans of Croatian origin. Some clans of Slavic origin joined the exile of the German medieval aristocracy. But nowhere was there such a phenomenon as such a massive "oblivion" and then "remembering" one's former ethnic origin (and at the same time a very small return to the former Orthodox faith). This phenomenon also influences the modern development of states on the lands of the former Grand Duchy of Lithuania. Many figures of politics, business and culture of these countries declare their (most often invented) Szlachta origin. The legacy of the Grand Duchy of Lithuania continues to become the main factor influencing the entire policy of these countries.

Thus, the history of the Grand Duchy of Lithuania is only to a small extent the history of the Lithuanian ethnic group. However, questioning the great past of Lithuanians in the form of the Grand Duchy of Lithuania is the gravest crime in the eyes of modern Lithuanian politicians. The modern British historian and political scientist Anatole Lieven, a direct descendant of the famous Ostsee family, noted: "When dealing with Lithuanian nationalist politicians, I was constantly convinced that they acted only partially in the present tense; their behaviour was based on a vision of how their actions would look like in the carnival of Lithuanian history, starting from the Grand Duchy of Lithuania and extending to future history textbooks" (Lieven, 1994). In Belarus, local nationalists use the concept of "Litvins" for the name of the inhabitants, as long as the word "Belarusian" does not sound, meaning the people are part of historical Russia. Flags, coats of arms, symbols of the Grand Duchy of Lithuania are an integral part of all nationalist demonstrations in the republic.

And it means that we will not get away from the history of the Grand Duchy of Lithuania and its elite for a long time. Further research is needed on this important issue to clear scientific data from political biases not only of yesterday but also of today.

\section{References:}

Act of the Union of Kreva on August 14, 1385. Retrieved June 5, 2021, from https://drevlit.ru/docs/litva/XIV/Jagailo/krev unija 1385d223.php

Borichevsky, I.P. (1851). Orthodoxy and Russian nationality in Lithuania. St Petersburg. Constitution of the Republic of Lithuania (2007, November 13). Adopted by the citizens of the Republic of Lithuania in a referendum on October 25, 1992. 
Entered into force on November 2, 1992. Retrieved June 5, 2021, from http://www3.lrs.lt/home/Konstitucija/Konstitucija RU.htm

Janusz Tazbir about the Sarmatians. The black legend of the Polish Szlachta is the work of priests (2008, January 9). Retrieved June 1, 2021, from https://public.wikireading.ru/113849

Kudryavtseva, R.A., \& Dvornichenko, A.Y. (2014). The specifics of the phenomenon of the Szlachta, the Szlachta class as the social base of the Grand ducal power in the Grand Duchy of Lithuania. Youth Scientific Forum: Social and Economic Sciences: electronic collection of articles based on the materials of the 12th International Student Scientific and Practical Conference, 5 (12), 66-78. Moscow: Publishing house "MCNO".

Leskinen, M.V. (2002). Myths and images of Sarmatism. The origins of the national ideology of the Polish-Lithuanian Commonwealth. Moscow: Institute of Slavic Studies of the Russian Academy of Sciences.

Lieven, A. (1994). The Baltic revolution. Estonia, Latvia, Lithuania and the path to independence. New Haven, Leningrad.

Presnyakov, A.E. (1939). Russian History Lectures. Vol. 2. Western Russia and the Lithuanian-Russian State. Moscow.

Tyurin, A.V. (2020, August 22). Mirages of the Grand Duchy of Lithuania. Retrieved June 5, 2021, from http://fan.lib.ru/t/tjurin a w/mirazhivkl.shtml Vujchik, A. (2020, November 16). Dreams of the Great Lehi. A fictional history of Poland. Retrieved March 15, 2021, from https://www.novayapolsha.pl/article/mechty-o-velikoi-lekhii-kakpsevdonauka-formiruet-populyarnuyu-istoriyu/ 